\title{
Research progress in the population differentiation and geographical adaptation of cotton
}

\author{
LI Fuguang ${ }^{1,2}$ (D)
}

\begin{abstract}
Recently, Du and his team revealed the genomic basis of population differentiation and geographical distribution of Chinese cultivated G. hirsutum (upland cotton). Our previous study showed that the large-scale inversions on chromosome A08 are widely distributed in a core collection of upland cotton and have driven population differentiation in G. hirsutum. With 3248 tetraploid cotton germplasms, He et al. identified new inversions on chromosome A06, and found these inversions together with those in chromosome A08 caused subpopulation differentiation Chinese cultivars that were highly consistent with their corresponding geographical distributions. This work provides new perspectives to further understand environmental adaptation of Chinese upland cotton germplasms.
\end{abstract}

Keywords: Gossypium hirsutum, Inversion, Introgression, Germplasm

In nature, species have evolved into a variety of ecotypes to adapt to different environments. The genetic basis of environmental adaptation is a major concern for all evolutionary biologists, including those who study crop plants. Gossypium hirsutum, a cultivated tetraploid cotton grown worldwide with good adaptability, accounts for more than $95 \%$ of the natural cotton fiber production (Niles and Feaster 1984; Wendel et al. 2010). Although, cotton breeders and researchers focus on fiber yield and fiber quality for decades, the genetic basis of cotton adaptability is still unknown.

In animals, large-scale structural variations are often accompanied by changes in complex traits, such as mimicry in butterflies (Jay et al. 2021; VanKuren et al. 2019; Zhang et al. 2017), social habits in ants (Avril et al. 2019; Pracana et al. 2017), and alternative mating behavior in ruffs (Küpper et al. 2016; Lamichhaney et al. 2016). In plants, adaptability-related

\footnotetext{
Correspondence: aylifug@caas.cn

'Zhengzhou Research Base, State Key Laboratory of Cotton Biology, Zhengzhou University, 450001 Zhengzhou, China

${ }^{2}$ Institute of Cotton Research of the Chinese Academy of Agricultural Sciences, 455000 Anyang, China
}

haplotypes have been identified in sunflower, located in genomic regions with high degrees of differentiation and accompanied by large-scale structural variation (Todesco et al. 2020). In crops, genetic differentiation always coexists with geographical distribution in both foxtail millet (Jia et al. 2013) and soybean (Zhou et al. 2015). These results implied that the genomic differentiation driven by structural variation functions might be related to environmental adaptation (Hoffmann and Rieseberg 2008; Wellenreuther and Bernatchez 2018).

In cotton, Du et al. (2018) found that Asian cotton (G. arboreum) was possibly domesticated in southern China, then gradually adapted to local environments as it moved northward, eventually categorized into three subpopulations. Genomic divergence was widely existed between G. hirsutum landraces and G. hirsutum cultivars populations (Nazir et al. 2021). Differentiation of upland cotton core collection had an obvious geographical distribution and phenotypic characteristics (Ma et al. 2018; Dai et al. 2020), which might be driven by three largescale inversions on chromosome A08 and A06 by

(C) The Author(s). 2021 Open Access This article is licensed under a Creative Commons Attribution 4.0 International License, which permits use, sharing, adaptation, distribution and reproduction in any medium or format, as long as you give appropriate credit to the original author(s) and the source, provide a link to the Creative Commons licence, and indicate if changes were made. The images or other third party material in this article are included in the article's Creative Commons licence, unless indicated otherwise in a credit line to the material. If material is not included in the article's Creative Commons licence and your intended use is not permitted by statutory regulation or exceeds the permitted use, you will need to obtain permission directly from the copyright holder. To view a copy of this licence, visit http://creativecommons.org/licenses/by/4.0/ 
directly comparing genome assembles and using population genetics approaches (Yang et al. 2019; Dai et al. 2020). This phenomenon was also found in other Upland cotton populations (He et al. 2019, 2020).

He et al. (2021) published a study in Nature Genetics that provided insights into the genomic basis of population differentiation and geographical distribution in cultivated G. hirsutum. Based on an analysis of genomic variation in 3248 tetraploid cotton germplasms, he and colleagues, mainly from the Institute of Cotton Research, Chinese Academy of Agricultural Sciences (ICR, CAAS), clearly illuminated large-scale inversions on chromosomes A06 and A08. Accessions differentiated by these inversions were highly consistent with their corresponding geographical distributions, which might determine the formation of different ecotypes in cultivated G. hirsutum. To confirm the origin of these chromosomal inversions, four major haplotypes were identified on chromosomes A06 and A08. Almost all Chinese registered cultivars carrying two A06-haplotypes and one A08-haplotype were geographically distributed in the highest- and lowest-latitude regions, respectively, exhibiting a regular distribution pattern. They found that the landraces carried these three haplotypes (A06-A08 haplotype) consistent with both chromosomes. This study therefore demonstrated that chromosomal inversions of A06 and A08 originated from a landrace and were related to geographic differentiation of cultivated G. hirsutum. They also comprehensively analyzed registered cultivars $(n=851)$ by integrating their A06-A08 haplotype combination and clearly described the genomic landscape of chromosomes A06 and A08 for cotton germplasm introduction, breeding preferences, and regional relocation in China.

This study revealed the genetic basis of population differentiation in Chinese upland cotton cultivars, and laid an important theoretical foundation for further understanding the adaptive evolution of G. hirsutum. This study could also guide new cultivars development to rapidly adapt Chinese Northwestern regions where has been the most important cotton cultivation region in recent years.

Additionally, this study comprehensively identified and evaluated the origin and effect of all favorable alleles related to fiber quality of G. hirsutum. Two new and favorable allelic variations were identified from introgression of the diploid species G. arboreum and G. thurberi, demonstrating that introgression of exogenous fragments and recombination of elite loci have great potential for enhancing fiber quality. Further identification causal genes of these new loci could accelerate to develop super fiber-quality cultivars in future.
Acknowledgements

Not applicable.

Author's contributions

Li F. wrote and revised this manuscript. The author(s) read and approved the final manuscript.

Funding

Not applicable.

Availability of data and materials

Not applicable.

\section{Declarations}

Ethics approval and consent to participate

Not applicable.

Consent for publication

Not applicable

\section{Competing interests}

Not applicable.

Received: 21 May 2021 Accepted: 10 June 2021

Published online: 02 August 2021

\section{References}

Avril A, Purcell J, Brelsford A, et al. Asymmetric assortative mating and queen polyandry are linked to a supergene controlling ant social organization. Mol Ecol. 2019;28(6):1428-38. https://doi.org/10.1111/mec.14793.

Dai P, Sun G, Jia Y, et al. Extensive haplotypes are associated with population differentiation and environmental adaptability in upland cotton (Gossypium hirsutum). Theor Appl Genet. 2020;133(12):3273-85. https://doi.org/10.1007/ s00122-020-03668-z

Du X, Huang G, He S, et al. Resequencing of 243 diploid cotton accessions based on an updated $A$ genome identifies the genetic basis of key agronomic traits. Nat Genet. 2018;50(6):796-802. https://doi.org/10.1038/s41588-018-011 $6-x$

He S, Sun G, Huang L, et al. Genomic divergence in cotton germplasm related to maturity and heterosis. J Integr Plant Biol. 2019;61(8):929-42. https://doi.org/1 $0.1111 / j i p b .12723$.

He S, Wang P, Zhang Y, et al. Introgression leads to genomic divergence and responsible for important traits in upland cotton. Front Plant Sci. 2020;11:929. https://doi.org/10.3389/fpls.2020.00929.

He S, Sun G, Geng X, et al. The genomic basis of geographic differentiation and fiber improvement in cultivated cotton. Nat Genet. 2021;53:916-24. https:// doi.org/10.1038/s41588-021-00844-9.

Hoffmann AA, Rieseberg LH. Revisiting the impact of inversions in evolution: from population genetic markers to drivers of adaptive shifts and speciation? Annu Rev Ecol Evol Syst. 2008;39:21-42. https://doi.org/10.1146/annurev. ecolsys.39.110707.173532.

Jay $\mathrm{P}$, Chouteau M, Whibley A, et al. Mutation load at a mimicry supergene sheds new light on the evolution of inversion polymorphisms. Nat Genet. 2021; 53(3):288-93. https://doi.org/10.1038/s41588-020-00771-1.

Jia G, Huang X, Zhi H, et al. A haplotype map of genomic variations and genome-wide association studies of agronomic traits in foxtail millet (Setaria italica). Nat Genet. 2013:45(8):957-61. https://doi.org/10.1038/ng.2673.

Küpper C, Stocks M, Risse JE, et al. A supergene determines highly divergent male reproductive morphs in the ruff. Nat Genet. 2016;48(1):79-83. https:// doi.org/10.1038/ng.3443.

Lamichhaney S, Fan G, Widemo F, et al. Structural genomic changes underlie alternative reproductive strategies in the ruff (Philomachus pugnax). Nat Genet. 2016;48(1):84-8. https://doi.org/10.1038/ng.3430.

Ma Z, He S, Wang X, et al. Resequencing a core collection of upland cotton identifies genomic variation and loci influencing fiber quality and yield. Nat Genet. 2018;50(6):803-13. https://doi.org/10.1038/s41588-018-0119-7.

Nazir MF, He S, Ahmed H, et al. Genomic insight into the divergence and adaptive potential of a forgotten landrace G. hirsutum L. purpurascens. J Genet Genomics. 2021; https://doi.org/10.1016/j.jgg.2021.04.009. (in press) 
Niles GA, Feaster CV. Breeding. In: Kohel RJ, Lewis CF, editors. Cotton. Madison: American Society of Agronomy, Crop Science Society of America, Soil Science Society of America; 1984. pp. 201-31. https://doi.org/10.2134/a gronmonogr24.c7.

Pracana R, Priyam A, Levantis I, et al. The fire ant social chromosome supergene variant Sb shows low diversity but high divergence from SB. Mol Ecol. 2017; 26(11):2864-79. https://doi.org/10.1111/mec.14054.

Todesco M, Owens GL, Bercovich N, et al. Massive haplotypes underlie ecotypic differentiation in sunflowers. Nature. 2020;584(7822):602-7. https://doi.org/1 0.1038/s41586-020-2467-6.

VanKuren NW, Massardo D, Nallu S, et al. Butterfly mimicry polymorphisms highlight phylogenetic limits of gene reuse in the evolution of diverse adaptations. Mol Biol Evol. 2019;36(12):2842-53. https://doi.org/10.1093/ molbev/msz194.

Wellenreuther M, Bernatchez L. Eco-evolutionary genomics of chromosoma inversions. Trends Ecol Evol. 2018;33(6):427-40. https://doi.org/10.1016/j.tree.2 018.04.002.

Wendel JF, Brubaker CL, Seelanan T. The origin and evolution of Gossypium. In: Stewart JM, Oosterhuis D, Heitholt JJ, Mauney JR, editors. Physiology of cotton. Dordrecht, Netherlands: Springer; 2010. p.1-18. https://doi.org/10.1 007/978-90-481-3195-2_1.

Yang Z, Ge X, Yang Z, et al. Extensive intraspecific gene order and gene structural variations in upland cotton cultivars. Nat Commun. 2019;10(1):1-13. https://doi.org/10.1038/s41467-019-10820-x.

Zhang W, Westerman E, Nitzany E, et al. Tracing the origin and evolution of supergene mimicry in butterflies. Nat Commun. 2017;8(1):1-11. https://doi. org/10.1038/s41467-017-01370-1.

Zhou Z, Jiang Y, Wang Z, et al. Resequencing 302 wild and cultivated accessions identifies genes related to domestication and improvement in soybean. Nat Biotechnol. 2015;33(4):408-14. https://doi.org/10.1038/nbt.3096.

Ready to submit your research? Choose BMC and benefit from:

- fast, convenient online submission

- thorough peer review by experienced researchers in your field

- rapid publication on acceptance

- support for research data, including large and complex data types

- gold Open Access which fosters wider collaboration and increased citations

- maximum visibility for your research: over $100 \mathrm{M}$ website views per year

At $\mathrm{BMC}$, research is always in progress.

Learn more biomedcentral.com/submissions 